\title{
Impact of Analog Rice Derived from Different Composite Flours from Tubers, Germinated Legumes, and Cereals on Improving Serum Markers in Alloxan-Induced Diabetic Rats
}

\author{
Mutiara Nugraheni, Sutriyati Purwanti, and Prihastuti Ekawatiningsih \\ Culinary Art Vocational Education, Faculty of Engineering, Yogyakarta State University, Yogyakarta 55281, Indonesia
}

\begin{abstract}
This study aimed to evaluate the consumption of four types of analog rice made from different composite flours in alloxan-induced diabetic rats. Forty-two male Wistar rats were divided into seven groups and fed different food for six weeks: normal standard food (NSF), diabetic standard food (DSF), diabetic commercial rice (DCR), and diabetic analog rice (DAR) I $\sim$ IV. Total phenolic, dietary fiber, and resistant starch contents were evaluated in every analog and commercial type of rice. The parameters studied were fasting blood glucose, homeostatic model assessment (HOMA) insulin resistance (IR), HOMA $\beta$, lipid profile, atherogenic indexes (AI), weight changes, serum insulin and antioxidant activities. Total phenol, dietary fiber, and resistant starch were higher for analog rice IV than the other three analog rice. In addition, analog rice IV had a greater ability to lower fasting blood glucose, total cholesterol, triglycerides, and low-density lipoprotein levels. High density lipoprotein levels increased in all groups fed analog rice, and all diabetic rats fed four types of analog rice had improved weight, antioxidant activity, serum insulin levels, HOMA IR, HOMA $\beta$, and AI. Commercial rice consumption did not improve glucose or lipids profiles, antioxidant activity, serum insulin level, HOMA IR, HOMA $\beta$, or AI in diabetic mice. These results show that the four types of analog rice significantly improved serum markers in diabetic rats.
\end{abstract}

Keywords: analog rice, antioxidant, germinated, HOMA $\beta$, insulin

\section{INTRODUCTION}

The prevalence of diabetes worldwide is estimated to increase by $5.4 \%$ in adults by 2025 . Basic Health Research data from Indonesia states that the prevalence of diabetes in Indonesia in individuals aged 15 years was $6.9 \%$ in 2013 and increased to 8.5\% in 2018 (Kementerian Kesehatan Republik Indonesia, 2018). Diabetes is a group of metabolic disorders characterized by hyperglycemia, which causes interference with insulin secretion, action, or both. Chronic hyperglycemia in diabetes is associated with long-term damage, dysfunction, and failure of different organs, especially the eyes, kidneys, nerves, heart, and blood vessels. Hyperglycemia is associated with excessive reactive oxygen species, oxidative stress, and inflammation, and leads to decreased insulin release and serious complications (Mahmoud et al., 2012; Tiwari et al., 2013). Therefore, agents capable of controlling hyperglycemia and oxidative stress are used to manage diabetes. Various studies have been conducted in vivo and in vitro to inves- tigate new treatments, hypoglycemic agents, or agents to reduce oxidative stress to control or treat diabetes. Local ingredients used to manufacture food may have functional potential as hypoglycemic and oxidative stress lowering agents.

Analog rice is a food made from non-rice carbohydrate sources, constituting tubers, legumes, and cereal flours. Modifying the process by autoclaving and cooling tuber flour tends to increase levels of resistant starch (Dundar and Gocmen, 2013; Reddy et al., 2014). Legumes and cereals are subjected to germination processes to minimize tannins, phytic acids, aromas, and their somewhat bitter tastes (Zhang et al., 2015; Sharma et al., 2016). Some studies have shown that germination processes induce beneficial functional properties, including lowering of glucose and lipids profiles in diabetic animals, and improve lipids profiles in animals fed high-fat diets (Aslani et al., 2015a; Aslani et al., 2015b; Asrullah et al., 2016; Liyanage et al., 2018). Indeed, germination processes impact on carbohydrate, protein, fat, and dietary fiber lev- 
els (Lemmens et al., 2019), and increase contents of bioactive compounds (Megat Rusydi and Azrina, 2012; Gan et al., 2017; López-Martínez et al., 2017), and elevation in antioxidant activity (Khang et al., 2016; Xue et al., 2016).

Extrusion technology is used to manufacture grains such as analog rice. This process tends to increase resistant starch (Raigond et al., 2015), which has functional properties to lower cholesterol and glycemic indexes, and to improve insulin sensitivity (Bindels et al., 2017; Jyoshna and Hymavathi, 2017; Nugraheni et al., 2017).

Some types of legumes used for analog rice, such as Glycine max (Ciabotti et al., 2016), Phaseolus vulgaris (SaiUt et al., 2009), Vigna radiata (Dahiya et al., 2015), and Vigna unguiculata (Devi et al., 2015), are sources of dietary fiber. Some cereals are also sources of dietary fiber, such as corn/Zea mays (Beloshapka et al., 2016) and Sorghum (Subagio and Aqil, 2014). The dietary fiber content of legumes and cereals has functional properties beneficial to human health. Analog rice is made from hydrocolloids, emulsifiers, tuber, cereal, and legume sprout flours. Combining constituent materials and process modifications in creation of analog rice is expected to produce products containing dietary fiber, resistant starch, and bioactive compounds, thus having potential to be developed as a functional food for management of diabetes.

This study aims to investigate the effect of consuming four types of analog rice on insulin, phenol, dietary fiber, starch resistant levels, plasma antioxidant activity, glucose, lipids profiles, atherogenic indexes (AI), homeostatic model assessment (HOMA) insulin resistance (IR), and HOMA $\beta$ in rats with diabetes.

\section{MATERIALS AND METHODS}

\section{Analog rice}

Four types of analog rice were used: analog rice I, II, III, and IV. Rice were selected based on results from sensory evaluation with 30 semi-trained panelists in previous study stages. The composition of analog rice constituents included natural and modified tuber flour (with the autoclaving-cooling process repeated for three cycles), legume flour, and cereals passed through the germination process. The autoclaving-cooling process was carried out according to Nugraheni et al. (2017). The germination process of red kidney bean (Phaseolus vulgaris L.) is reported by Audu and Aremu (2011), white Sorghum is reported by Elkhalifa and Bernhardt (2010), yellow and white corn is reported by Chalorcharoenying et al. (2017), cowpea/Vigna unguiculata is reported by Devi et al. (2015), and mung bean or Vigna radiata is reported by Megat Rusydi et al. (2011). The ingredients used for the manufacture of the four types of analog rice are in Table 1. Other ingredients included hydrocolloid, glycerol mono- stearate (GMS), coconut oil, and water. The manufacturing process was carried out by mixing all dry ingredients until uniform, then mixing ingredients with hydrocolloids, GMS, coconut oil and water. This was performed using an extruder machine with a $900 \mathrm{rpm}$ at $120^{\circ} \mathrm{C}$ to ensure that the resulting product has a rice-like shape.

\section{Extraction process}

Extraction of four types of analog rice was conducted by the maceration method using solvents, namely ethanol. The ratio of analog rice to solvent was 1:5 (w/v), and maceration was carried out for seven days. Afterward, the solution was filtered with Whatman no. 1 filter paper and evaporated using a rotary evaporator to remove the solvent. The extracts were stored at $-22^{\circ} \mathrm{C}$.

\section{Determination of total phenol}

Total phenol levels were determined by the spectrophotometric method (Singleton et al., 1999). A total of 0.2 $\mathrm{mL}$ of the four types of analog rice ethanol extracts (100 $\mathrm{mg} / \mathrm{L}$ ) was added to $2.5 \mathrm{~mL}$ of reagent Folin-Ciocalteu and $2 \mathrm{~mL}$ of $7.5 \% \mathrm{Na}_{2} \mathrm{CO}_{3}$. The mixture was allowed to stand for $15 \mathrm{~min}$ at $45^{\circ} \mathrm{C}$ before the absorbance was measured using a spectrophotometer at a wavelength of $765 \mathrm{~nm}$. Total phenol levels were expressed in mg gallic acid equivalents/100 g dried extract.

Table 1. Ingredients in the four types of analog rice (unit: \%)

\begin{tabular}{lc}
\hline & Proportion \\
\hline Analog rice I & \\
Cassava (Manihot esculenta) flour & 25 \\
Modified cassava (Manihot esculenta) flour & 5 \\
Germinated Glycine max flour & 20 \\
Germinated Sorghum flour & 20 \\
Sago starch & 30 \\
Analog rice II & \\
Canna edulis flour & 25 \\
Modified Canna edulis & 5 \\
Germinated Phaseolus vulgaris flour & 20 \\
Germinated white Sorghum & 20 \\
Sago starch & 30 \\
Analog rice III & \\
Orange Ipomea batatas flour & 25 \\
Modified orange Ipomea batatas & 5 \\
Germinated Vigna unguiculate flour & 20 \\
Germinated yellow Zea mays flour & 20 \\
Sago starch & 30 \\
Analog rice IV & \\
White Ipomea batatas & 25 \\
Modified white Ipomea batatas & 5 \\
Germinated Vigna radiata flour & 20 \\
Germinated white Zea mays flour & 20 \\
Sago starch & 30 \\
\hline
\end{tabular}




\section{Determination of total dietary fiber (TDF)}

TDF was measured by the enzymatic-gravimetric AOAC method (Lee et al., 1992). A total of $0.5 \mathrm{~g}$ of defatted four types of analog rice was added into an Erlenmeyer flask, with $25 \mathrm{~mL}$ of $0.08 \mathrm{M}$ phosphate buffer ( $\mathrm{pH} \mathrm{6.0)}$ and 50 $\mu \mathrm{L}$ of $\alpha$-amylase. The mixture was then incubated at $95^{\circ} \mathrm{C}$ for $30 \mathrm{~min}$ and cooled. When the mixture reached $\mathrm{pH}$ $7.5,5 \mathrm{~mL}$ of $0.275 \mathrm{~N} \mathrm{NaOH}$ was added. The mixture was then incubated at $60^{\circ} \mathrm{C}$ for $30 \mathrm{~min}$ in a swaying water bath at $\mathrm{pH} 4.5$ with $0.325 \mathrm{~N} \mathrm{HCl}$. Amyloglucosidase (150 $\mu \mathrm{L})$ was then added and the mixture was further incubated at $60^{\circ} \mathrm{C}$ for $30 \mathrm{~min}$ and filtered. To determine the TDF content, the rice was treated with a $95 \%(v / v)$ ethanol (ethanol/rice analog ratio of 4:1) at room temperature for $1 \mathrm{~h}$ to precipitate the soluble fiber and remove depolymerized proteins and glucose from starch. The residues were filtered on G4-sintered glass and washed sequentially with $78 \%$ and $95 \%(\mathrm{v} / \mathrm{v})$ ethanol and absolute acetone, and dried to a constant weight at $40^{\circ} \mathrm{C}$ (Lee et al., 1992; Mandalari et al., 2010).

\section{Determination of resistant starch}

Resistant starch was isolated according to the method described by Zhang and Jin (2011). A total of $1 \mathrm{~g}$ of four types of analog rice was weighed and poured into a bioreactor containing $100 \mathrm{~mL}$ of distilled water, and the mixture was heated by circulating hot water from a water bath equipped with a pump. When the internal temperature of the bioreactor reached $95^{\circ} \mathrm{C}, 0.5 \mathrm{~mL}$ of $\alpha$-amylase was added, and the slurry was incubated at a specific temperature for $30 \mathrm{~min}$. The reaction mixture was then cooled at room temperature, and centrifuged at 5,000 $\mathrm{g}$ for $10 \mathrm{~min}$. The resulting residue was resuspended in 100 $\mathrm{mL}$ of phosphate buffer $(0.08 \mathrm{M}, \mathrm{pH} 7.5)$ and treated with protease $(0.5 \mathrm{~mL})$ for $30 \mathrm{~min}$ at $60^{\circ} \mathrm{C}$. Subsequently, the $\mathrm{pH}$ was adjusted to 4.5 with dilute $\mathrm{HCl}$. Amyloglucosidase $(0.5 \mathrm{~mL})$ was then added, the mixture was incubated at $60^{\circ} \mathrm{C}$ for $30 \mathrm{~min}$, and the suspension was centrifuged at $5,000 \mathrm{~g}$ for $10 \mathrm{~min}$. The insoluble residue was washed several times with distilled water, washed twice with $80 \%$ and $95 \%(\mathrm{v} / \mathrm{v})$ ethanol, and then dried at $40^{\circ} \mathrm{C}$ overnight in a vacuum oven to recover resistant starch.

\section{Determination of fasting glucose levels, body weights, and feed efficiency ratios in rats}

A total of 42 male Wistar rats aged 10 weeks and weighing 150 200 g were included. Rats were caged under conditions, including controlled light, adequate air ventilation, $28 \sim 32^{\circ} \mathrm{C}$ temperature, and $58 \pm 4 \%$ humidity. Rats are fed standard feed using the 1993 AIN standard for 7 days (Reeves et al., 1993). The ethics commission approved the experimental animals' treatment through certificate number: 154.3/FIKES/PL/VII/2020.

The experimental phase included acclimatization be- fore induction for 7 days, then the groups to be injected were satisfied one night. The rats were intraperitoneally injected with a single dose of $125 \mathrm{mg} / \mathrm{kg}$ alloxan monohydrate dissolved in aquades. Post induction, rats were acclimatized for 5 days. Rats were declared diabetic when blood glucose levels were $150 \mathrm{mg} / \mathrm{dL}$ (Agunbiade et al., 2012). The experimental rats were divided into 7 groups of 6 :

- Group I: Normal rats (without alloxan induction) fed a standard feed diet of AIN 93 (NSF)

- Group II: Alloxan-induced rats fed a standard diet of AIN 93 (DSF)

- Group III: Diabetic rats fed a commercial rice diet (DCR)

- Group IV: Diabetic rats fed the analog rice diet I (DAR I)

- Group V: Diabetic rats fed the analog rice diet II (DAR II)

- Group VI: Diabetic rats fed the analog rice diet III (DAR III)

- Group VII: Diabetic rats fed the analog rice diet IV (DAR IV)

Rats were fed standard feed or analog/commercial rice (C64) at 15 g per day for 42 days, with drinking water available ad libitum. Every day, the cage and sewage shelter were cleaned of impurities and attached stools, and the rest of the feed was weighed. Rats were weighed every two days and the food efficiency ratio (FER) was calculated as follows:

$$
\mathrm{FER}=\frac{\begin{array}{c}
\mathrm{g} \text { of body weight gains during } \\
\text { the experimental period }
\end{array}}{\mathrm{g} \text { of food intakes during the experimental period }}
$$

The rats were fed every morning, and blood was obtained at the beginning and end of treatment to analyze glucose and lipid profiles. Blood was retrieved often from the orbital sinuses at a volume of $1.5 \mathrm{~mL}$. Blood glucose analysis was conducted following the method of glucose oxidase-phenol amino phenazone (GOD-PAP), the enzymatic reaction photometric test. Fasting glucose levels were determined by the enzymatic method using glucose oxidase-phenol 4-aminoantipirin. Serum glucose levels were determined using an analysis kit from DiaSys Diagnostic Systems GmbH (Holzheim, Bayern, Germany) consisting of standard and reagent solutions; $10 \mu \mathrm{L}$ serum was added to up to $1,000 \mu \mathrm{L}$ GOD-PAP reagents and mixtures were vortexed. Solutions were incubated at room temperature for $20 \mathrm{~min}$ at $20 \sim 25^{\circ} \mathrm{C}$, and measured using a spectrophotometer at a wavelength of $500 \mathrm{~nm}$. Fasting blood glucose $(\mathrm{mg} / \mathrm{dL})$ was calculated as follows:

$$
\text { Fasting blood glucose }=\frac{\Delta \text { Sample }}{\Delta \text { Standard }} \times \text { Standard }
$$


Determination of serum lipid level and AI

Lipids profiles [triglycerides, total cholesterol, low-density lipoprotein cholesterol (LDL-c), and high-density lipoprotein cholesterol (HDL-c)] were measurement (Zou et al., 2005). AI were measured as follows (Muruganandan et al., 2005):

$$
\mathrm{AI}=\frac{\text { Total cholesterol }- \text { HDL-c }}{\text { HDL-c }}
$$

\section{Determination of plasma antioxidants with ferric reducing ability of plasma (FRAP)}

Evaluation of plasma antioxidant capacity was conducted by the FRAP method (Benzie and Strain, 1996). A total of $30 \mu \mathrm{L}$ of FRAP reagents at $37^{\circ} \mathrm{C}$ were added to $10 \mu \mathrm{L}$ of plasma samples $/ \mathrm{FeSO}_{4} \cdot 7 \mathrm{H}_{2} \mathrm{O}$ standard solution, followed by $30 \mu \mathrm{L}$ aquades. Mixtures were vortexed then incubated for $5 \mathrm{~min}$ at $37^{\circ} \mathrm{C}$. The absorbance of the mixture was determined at a wavelength of $593 \mathrm{~nm}$. FRAP reagents were created by mixing $25 \mathrm{~mL}$ of acetate buffer at $\mathrm{pH} 3.6$ with $2.5 \mathrm{~mL}$ of 2,3,5-triphenyltetrazolium chloride solution and $2.5 \mathrm{~mL}$ of $\mathrm{FeCl}_{3} \cdot 6 \mathrm{H}_{2} \mathrm{O}$ solution. $\mathrm{FeSO}_{4}$ standard solutions were made at concentrations of 100 $1,000 \mu \mathrm{mol} / \mathrm{L}$ to formulate the standard curve.

\section{Determination of fasting insulin levels}

Fasting insulin levels were measured in serum separated from blood samples by monoclonal anti-insulin (antibodies) coating the base of microplate wells, using reagents available in DRG insulin ELISA kits (catalog number: EIA 2048, DRG International, Inc., Springfield, NJ, USA). A total $10 \mu \mathrm{L}$ of serum and calibrator were added into each well, followed by $100 \mu \mathrm{L}$ of enzyme conjugate buffer. The content of each well was then discarded by reversing the microplate and wells were washed six times with $350 \mu \mathrm{L}$ of the washing solution. Next, $200 \mu \mathrm{L}$ of $3,3^{\prime}, 5,5^{\prime}$-tetramethylbenzidine substrate was added to each well and reactions were incubated for $15 \mathrm{~min}$ at room temperature. Then, $50 \mu \mathrm{L}$ of stop solution was added to each, reactions were incubated for $5 \mathrm{~s}$, and then measured using a microplate reader at a wavelength of $450 \mathrm{~nm}$. Insulin levels were expressed in units $\mu \mathrm{g} / \mathrm{L}$.

Determination of HOMA IR and HOMA $\beta$ were calculated as determined by Wallace et al. (2004) after dietary treatment with four types of analog rice:

$$
\begin{aligned}
& \text { HOMA IR }= \\
& \frac{\text { Fasting insulin }\left(\frac{\mathrm{mg}}{\mathrm{mL}}\right) \times \text { Fasting glucose }\left(\frac{\mathrm{mg}}{\mathrm{dL}}\right)}{405}
\end{aligned}
$$

$$
\text { HOMA } \beta=\frac{360 \times \text { Fasting plasma insulin }\left(\frac{\mu g}{\mathrm{~L}}\right)}{\text { Fasting blood glucose }\left(\frac{\mathrm{mg}}{\mathrm{dL}}\right)-63}
$$

\section{Statistical analysis}

Statistical analysis was conducted using SPSS software (version 16, SPSS Inc., Chicago, IL, USA). Data were analyzed by randomized complete block design followed by Duncan's multiple range test to determine significant difference between the sample means $(P \leq 0.05)$.

\section{RESULTS}

Total phenolic, dietary fiber, and resistant starch content The amount of total phenol, dietary fiber, and resistant starch in the four types of analog rice varied according to the constituent material's composition (Table 2). The four types of analog rice had significantly different total phenol, dietary fiber, and resistant starch contents compared with commercial rice $(P<0.05)$. Analog rice IV had a higher total phenol, dietary fiber, and resistant starch content than analog rice I $\sim$ III.

\section{Determination of glucose level, body weight, and food efficiency ratio}

The effect of four types of analog rice consumption treatment for 42 days on fasting glucose levels is shown in Table 3. The decrease in glucose was shown in rats fed the analog rice (I, II, III, and IV). Consumption of commercial rice (C64) was unable to lower blood glucose levels of the diabetic rats. Definitive treatment of glucose levels in mice fed the $\mathrm{C} 64$ rice diet did not differ significantly from diabetic mice fed the standard feed $(P<0.05)$. Rice analogs I, II, III, and IV reduced blood glucose levels in diabetic rats by $48.07 \%, 61.60 \%, 63.58 \%$, and $66.12 \%$, respectively (Fig. 1). The analog rice IV diet was more successful in lowering blood glucose levels compared with analog rice I $\sim$ III.

Table 2. Total levels of phenol, dietary fiber, and resistant starch in analog and commercial rice (C64)

\begin{tabular}{lcrc}
\hline \multicolumn{1}{c}{ Rice } & $\begin{array}{c}\text { Total phenol } \\
\text { content } \\
\text { (mg GAE/100g) }\end{array}$ & $\begin{array}{c}\text { Dietary } \\
\text { fiber } \\
\text { content (\%) }\end{array}$ & $\begin{array}{c}\text { Resistant } \\
\text { starch } \\
\text { content (\%) }\end{array}$ \\
\hline DAR I & $335.35 \pm 0.70^{\mathrm{c}}$ & $17.55 \pm 0.29^{\mathrm{b}}$ & $2.06 \pm 0.24^{\mathrm{b}}$ \\
DAR II & $255.65 \pm 0.34^{\mathrm{b}}$ & $19.64 \pm 0.19^{\mathrm{d}}$ & $2.61 \pm 0.13^{\mathrm{c}}$ \\
DAR III & $346.50 \pm 0.85^{\mathrm{d}}$ & $19.81 \pm 0.45^{\mathrm{e}}$ & $3.27 \pm 0.09^{\mathrm{d}}$ \\
DAR IV & $352.50 \pm 1.13^{\mathrm{e}}$ & $22.11 \pm 0.10^{\mathrm{e}}$ & $3.43 \pm 0.11^{\mathrm{e}}$ \\
Commercial rice & $167.00 \pm 0.02^{\mathrm{a}}$ & $3.28 \pm 0.03^{\mathrm{a}}$ & $1.69 \pm 0.21^{\mathrm{a}}$ \\
\hline
\end{tabular}

Values presented are mean \pm SD $(n=3)$.

Means in columns with different letters (a-e) are significantly different $(P<0.05)$. 
Table 3. Effect of rice on body weight gain, food intake, and FERs of alloxan-induced diabetic rats over six weeks

\begin{tabular}{lcccrr}
\hline Group & Initial body weight (g) Final body weight (g) & $\begin{array}{c}\text { Bodyweight gain } \\
\text { (g/period) }\end{array}$ & $\begin{array}{r}\text { Food intakes } \\
\text { (g/period) }\end{array}$ & FER \\
\hline NSF & $186.50 \pm 4.61^{\mathrm{b}}$ & $228.00 \pm 5.87^{\mathrm{e}}$ & $41.50 \pm 1.05^{\mathrm{c}}$ & $520.67 \pm 4.57^{\mathrm{a}}$ & $0.08 \pm 0.00^{\mathrm{c}}$ \\
DSF & $175.00 \pm 3.29^{\mathrm{a}}$ & $142.17 \pm 2.52^{\mathrm{a}}$ & $-20.50 \pm 3.14^{\mathrm{a}}$ & $594.67 \pm 5.24^{\mathrm{d}}$ & $-0.04 \pm 0.01^{\mathrm{a}}$ \\
DCR & $176.33 \pm 3.44^{\mathrm{a}}$ & $155.00 \pm 3.84^{\mathrm{b}}$ & $-22.50 \pm 4.92^{\mathrm{a}}$ & $601.17 \pm 4.12^{\mathrm{d}}$ & $-0.38 \pm 0.01^{\mathrm{a}}$ \\
DAR I & $176.00 \pm 3.36^{\mathrm{a}}$ & $200.33 \pm 2.55^{\mathrm{c}}$ & $17.00 \pm 1.87^{\mathrm{a}}$ & $557.00 \pm 4.17^{\mathrm{c}}$ & $0.03 \pm 0.01^{\mathrm{b}}$ \\
DAR II & $190.33 \pm 3.57^{\mathrm{bc}}$ & $217.83 \pm 4.67^{\mathrm{d}}$ & $26.83 \pm 1.83^{\mathrm{bc}}$ & $548.67 \pm 3.55^{\mathrm{c}}$ & $0.05 \pm 0.00^{\mathrm{bc}}$ \\
DAR III & $199.83 \pm 4.97^{\mathrm{d}}$ & $234.83 \pm 3.43^{\mathrm{e}}$ & $33.67 \pm 4.03^{\mathrm{bc}}$ & $550.17 \pm 4.57^{\mathrm{c}}$ & $0.06 \pm 0.01^{\mathrm{c}}$ \\
DAR IV & $197.83 \pm 3.60^{\mathrm{cd}}$ & $233.00 \pm 3.35^{\mathrm{e}}$ & $34.83 \pm 1.47^{\mathrm{c}}$ & $535.83 \pm 12.02^{\mathrm{b}}$ & $0.06 \pm 0.01^{\mathrm{c}}$ \\
\hline
\end{tabular}

Values presented are mean \pm SD $(n=6)$.

Means in columns with different superscripts are significantly different $(P<0.05)$.

FER, food efficiency ratio (body weight gain/food intake); DAR I, diabetic analog rice I; DAR II, diabetic analog rice II; DAR III, diabetic analog rice III; DAR IV, diabetic analog rice IV; DCR, diabetic commercial rice; DSF, diabetic standard feed; NSF, normal standard feed.

Induction of alloxan in rats evaluated the potential hypoglycemia of the four types of analog rice to increase glucose levels (i.e., increasing diabetes). This study demonstrated that the four types of analog rice (I, II, III, and IV) tends to lower plasma fasting glucose levels in alloxan-induced diabetic rats. The results of measuring blood glucose levels after six weeks of intervention were shown in Fig. 1. Blood glucose levels after alloxan induction increased above $200 \mathrm{mg} / \mathrm{dL}$ in all groups; this condition was classified as hyperglycemia characterized by above-normal glucose levels. Alloxan damages pancreatic $\beta$-Langerhans cells, leading to decreased insulin secretion, which induces diabetes mellitus.

The four types of analog rice significantly improved weight and FER of diabetic rats compared with those fed commercial rice DSF (Table 3). Indeed, the commercial rice was not able to improve the food efficiency ratio. Rats fed with four types of analog rice had lower food intake than rats fed DSF and DCR, but higher food intake than healthy rats $(P<0.05)$. FERs describe body weight gain relative to food intake; the FER of diabetic rats fed the four types of analog rice was significantly lower than that for normal or healthy rats $(P<0.05)$.

\section{Serum lipid profiles and Al}

The four types of analog rice consumption can improve serum lipid profiles of rats with diabetes mellitus. We observed significant reductions in serum triglycerides, total cholesterol, and LDL-c, and increases in HDL-c (Table 4). Analog rice I, II, III, and IV tended to lower triglyceride, total cholesterol, and LDL-c levels in diabetic rats to levels similar to those in healthy/normal rats. C64 did not lower triglycerides, total cholesterol, or LDL-c levels in diabetic rats. The lipid profiles of diabetic rats fed the C64 rice diet did not differ from those of diabetic rats fed the standard feed $(P<0.05)$. Furthermore, diabetic rats fed with four types of analog rice tended to have low AI (Table 4), whereas diabetic rats fed C64 rice had AI that did not significantly differ from those of diabetic rats fed

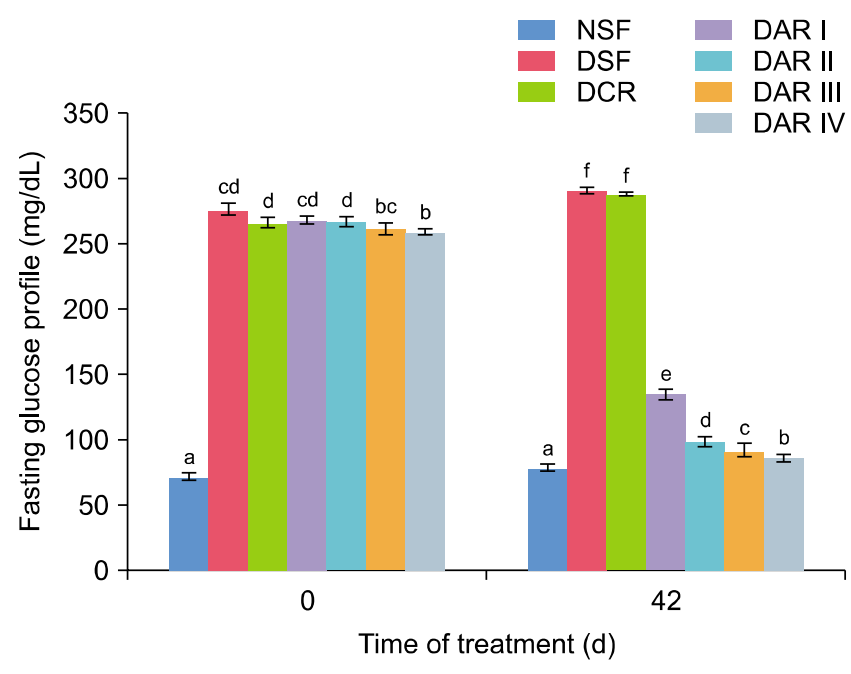

Fig. 1. Changes in fasting blood glucose levels after consumption of analog and commercial rice in diabetic rats. Data are mean \pm standard deviation ( $\mathrm{n}=6$ in each group). Different letters (a-f) are significantly different $(P<0.05)$. DAR I, diabetic analog rice I; DAR II, diabetic analog rice II; DAR III, diabetic analog rice III; DAR IV, diabetic analog rice IV; DCR, diabetic commercial rice; DSF, diabetic standard feed; NSF, normal standard feed.

standard feed. Diabetic rats fed analog rice IV for 6 weeks had the lowest AI compared with diabetic rats fed analog rice I, II, or III. The AI of the six groups of diabetic rats did not differ in the first week after alloxan induction $(P<0.05)$, but was higher than those of normal/ healthy rats.

\section{Antioxidant activity, serum insulin levels, HOMA-IR, and HOMA- $\beta$ scores}

The four types of analog feed can increase antioxidant activity in diabetic rats (Table 5). Analog rice III and IV showed the high antioxidant activity and did not statistically differ $(P<0.05)$. Furthermore, the antioxidant activity of diabetic rats fed $\mathrm{C} 64$ rice did not differ from those fed standard feed (control). The diabetic rats fed analog rice I, II, III, and IV had higher insulin levels than control rats and rats fed $\mathrm{C} 64$ rice. These results showed an in- 
Table 4. Effect of rice on serum lipid profiles and AI of non-diabetic and diabetic rats

\begin{tabular}{lccccc}
\hline Group & Triglycerides & Total cholesterol & HDL-c & LDL-c & AI \\
\hline NSF & $81.67 \pm 3.08^{\mathrm{a}}$ & $125.18 \pm 2.13^{\mathrm{b}}$ & $73.50 \pm 1.38^{\mathrm{f}}$ & $35.33 \pm 1.63^{\mathrm{a}}$ & $0.70 \pm 0.15^{\mathrm{a}}$ \\
DSF & $136.50 \pm 3.27^{\mathrm{e}}$ & $145.64 \pm 2.57^{\mathrm{d}}$ & $33.17 \pm 1.18^{\mathrm{a}}$ & $85.17 \pm 2.32^{\mathrm{d}}$ & $3,38 \pm 0.28^{\mathrm{f}}$ \\
DCR & $138.17 \pm 3.66^{\mathrm{e}}$ & $146.21 \pm 2.13^{\mathrm{e}}$ & $32.12 \pm 1.03^{\mathrm{a}}$ & $86.83 \pm 3.25^{\mathrm{d}}$ & $3.54 \pm 0.16^{\mathrm{g}}$ \\
DAR I & $99.00 \pm 1.67^{\mathrm{d}}$ & $125.30 \pm 2.32^{\mathrm{b}}$ & $58.17 \pm 1.72^{\mathrm{b}}$ & $47.33 \pm 4.18^{\mathrm{c}}$ & $1.15 \pm 0.13^{\mathrm{e}}$ \\
DAR II & $94.33 \pm 2.16^{\mathrm{c}}$ & $126.19 \pm 2.06^{\mathrm{c}}$ & $63.83 \pm 1.72^{\mathrm{c}}$ & $43.50 \pm 2.26^{\mathrm{b}}$ & $0.98 \pm 0.13^{\mathrm{d}}$ \\
DAR III & $88.50 \pm 2.25^{\mathrm{b}}$ & $124.04 \pm 2.18^{\mathrm{a}}$ & $69.17 \pm 2.32^{\mathrm{d}}$ & $37.17 \pm 1.72^{\mathrm{a}}$ & $0.78 \pm 0.11^{\mathrm{c}}$ \\
DAR IV & $86.00 \pm 1.79^{\mathrm{b}}$ & $125.20 \pm 3.26^{\mathrm{b}}$ & $72.67 \pm 1.75^{\mathrm{e}}$ & $35.33 \pm 2.25^{\mathrm{a}}$ & $0.73 \pm 0.07^{\mathrm{b}}$ \\
\hline
\end{tabular}

Values presented are mean \pm SD $(n=6)$.

Means in columns with different letters $(a-f)$ are significantly different $(P<0.05)$.

AI, atherogenic index; DAR I, diabetic analog rice I; DAR II, diabetic analog rice II; DAR III, diabetic analog rice III; DAR IV, diabetic analog rice IV; DCR, diabetic commercial rice; DSF, diabetic standard feed; HDL-c, high density lipoprotein cholesterol; LDL-c, low density lipoprotein cholesterol; NSF, normal standard feed.

Table 5. Effects of rice on antioxidant activity, serum insulin, HOMA IR, and HOMA $\beta$

\begin{tabular}{lcccc}
\hline Group & FRAP (\%) & Insulin $(\mathrm{ng} / \mathrm{mL})$ & HOMA IR & HOMA $\beta$ \\
\hline NSF & $78.00 \pm 2.28^{\mathrm{e}}$ & $0.58 \pm 0.01^{\mathrm{a}}$ & $0.12 \pm 0.00^{\mathrm{a}}$ & $11.07 \pm 1.18^{\mathrm{f}}$ \\
DSF & $15.50 \pm 1.87^{\mathrm{a}}$ & $0.42 \pm 0.01^{\mathrm{b}}$ & $0.30 \pm 0.00^{\mathrm{e}}$ & $0.67 \pm 0.12^{\mathrm{a}}$ \\
DCR & $15.83 \pm 1.47^{\mathrm{a}}$ & $0.41 \pm 0.00^{\mathrm{a}}$ & $0.29 \pm 0.00^{\mathrm{e}}$ & $0.65 \pm 0.01^{\mathrm{a}}$ \\
DAR I & $52.83 \pm 2.23^{\mathrm{b}}$ & $0.50 \pm 0.00^{\mathrm{c}}$ & $0.17 \pm 0.01^{\mathrm{d}}$ & $2.38 \pm 0.11^{\mathrm{b}}$ \\
DAR II & $61.33 \pm 1.63^{\mathrm{c}}$ & $0.53 \pm 0.00^{\mathrm{d}}$ & $0.14 \pm 0.01^{\mathrm{c}}$ & $4.69 \pm 0.50^{\mathrm{c}}$ \\
DAR III & $69.83 \pm 2.04^{\mathrm{d}}$ & $0.54 \pm 0.01^{\mathrm{e}}$ & $0.13 \pm 0.01^{\mathrm{b}}$ & $5.89 \pm 0.84^{\mathrm{d}}$ \\
DAR IV & $70.83 \pm 2.23^{\mathrm{d}}$ & $0.55 \pm 0.00^{\mathrm{f}}$ & $0.12 \pm 0.01^{\mathrm{a}}$ & $7.62 \pm 0.84^{\mathrm{e}}$ \\
\hline
\end{tabular}

Values presented are mean $\pm \mathrm{SD}(\mathrm{n}=6)$.

Means in columns with different letters $(a-f)$ are significantly different $(P<0.05)$.

DAR I, diabetic analog rice I; DAR II, diabetic analog rice II; DAR III, diabetic analog rice III; DAR IV, diabetic analog rice IV; DCR, diabetic commercial rice; DSF, diabetic standard feed; NSF, normal standard feed.

crease in insulin levels in rats fed with analog rice I IV compared with diabetic rats $(19.00 \%, 26.00 \%, 28.57 \%$, and $30.95 \%$, respectively).

HOMA IR scores of rats fed with four types of analog rice were smaller than scores for diabetic control rats and rats fed C64 rice. Furthermore, HOMA IR scores in diabetic rats (control) did not differ significantly from those given $\mathrm{C} 64$ rice feed. In addition, HOMA $\beta$ scores of diabetic mice fed four types of analog rice were greater than those of both control and rats fed C64 rice. However, HOMA $\beta$ scores of diabetic rats fed $\mathrm{C} 64$ rice did not noticeably differ from those of control rats $(P<0.05)$.

\section{DISCUSSION}

Diabetes is a severe endocrine disorder caused by disruption of intermediary metabolism via insufficient activity or impaired insulin secretion, or both. Diabetes is characterized by the presence of oxidative stress resulting from hyperglycemia, hyperinsulinemia, and insulin resistance. Free radicals produced in large quantities tend to cause a wide range of effects in diabetics, and appropriate strategies are needed to lower oxidative stress, glucose levels and lipids profiles. Therefore, there is a benefit for developing foods with antioxidant, hypoglycemic, hypocholes- terolemic, and hypolipidemic activities.

Total phenol, dietary fiber and resistant starch contents in foods can positively impact serum marker profiles in alloxan-induced diabetic rats. In this study, four types of analog rice was formulated from non-rice carbohydrate sources. The four types of analog rice was formulated from tubers, legumes, and cereal flour legumes to exhibit particular functional properties that improve glucose and lipid profiles in diabetic rats.

The chemical analysis results showed that the total phenol, dietary fiber, and resistant starch contents of the four types of analog rice varied, with analog rice IV having a higher content compared with the other three types. This has an impact on its ability to improve glucose and lipid profiles in alloxan-induced diabetic rats.

The differences in total phenol, dietary fiber, and resistant starch contents of the four types of analog rice and C64 rice are due to the different constituent ingredients and the different germination process of the legumes and cereals. The germination process tends to increase bioactive compounds and their antioxidant activity. The endogenous enzymes in legumes and cereals activated during germination were capable of altering chemical compositions. The enzymes most directly related to phenol were hydrolases and polyphenol oxidases, which have activities that increase during germination, dependent on 
the type of cereal and legume. This is in line with a study that stated the germination process of Glycine max, Phaseolus vulgaris, Vigna radiata, Vigna unguiculata, Zea mays, and sorghum increases levels of bioactive compounds and their antioxidant activities (Megat Rusydi and Azrina, 2012; Khang et al., 2016; Xue et al., 2016; Gan et al., 2017; López-Martínez et al., 2017).

Chemical analysis of the four types of analog rice showed that DAR I $\sim$ IV contain high dietary fiber contents compared with that of commercial rice (Foschia et al., 2013). The fiber source in the rice was from its constituent raw materials, namely legumes and cereals including Glycine max, Phaseolus vulgaris, Vigna radiata, Vigna unguiculata, Zea mays, and sorghum (Sai-Ut et al., 2009; Subagio and Aqil, 2014; Dahiya et al., 2015; Devi et al., 2015; Beloshapka et al., 2016; Ciabotti et al., 2016).

The four types of analog rice contained larger amounts of resistant starch than commercial rice (C64). The resistant starch content in the raw materials and the four types of analog rice improving glucose and lipid profiles in alloxan-induced diabetic rats. The process in generating analog rice can be modified to increase the resistant starch content, for example, through modifying tuber flour by autoclaving-cooling and extrusion processes. In this study, the modified tuber flour was modified by three cycles of autoclaving-cooling, and extrusion to form analog rice grains with increased the resistant starch content (Raigond et al., 2015; Nugraheni et al., 2017). The autoclaving-cooling process increased the resistant starch content since starch is gelatinized at temperatures above $100^{\circ} \mathrm{C}$ while under pressure. During this time, starch granules became thoroughly disrupted and, after cooling, amylase chains combine to form hydrogen bond stabilized double helices. In turn, these form RS3 crystallites, which cannot be broken down by starch hydrolyzing enzymes (Dundar and Gocmen, 2013). In addition, the extrusion process increased the resistant starch content. This tends to be due to the high force in the extruder, which can cause depolymerization of the starch, leading to production of a straight-chain followed by thermal cleavage of the molecules, creating straight chains highly expected to be retrograded to RS-3 (AgustinianoOsornio et al., 2005).

This study demonstrated that the four types of analog rice tended to lower plasma fasting glucose levels in alloxan-induced diabetic mice. The total phenol in the four types of analog rice can lower postprandial blood glucose. Soybeans (Glycine max) and mung bean (Vigna radi$a t a)$, which are constituents of analog rice, can inhibit $\alpha$ amylase and $\alpha$-glucosidase activities, which have essential roles in carbohydrate digestion, thus lowering blood glucose levels (Sreerama et al., 2012; Ademiluyi and Oboh, et al., 2013; Pantidos et al., 2014). Red kidney beans (Phaseolus vulgaris) also contain $\alpha$-amylase inhibitor isoform 1, which exhibits starch-blocking mechanisms that decrease postprandial plasma glucose (Obiro et al., 2008). The dietary fiber content in four types of analog rice had a positive impact on decreasing fasting blood glucose levels. Dietary fiber provides physiological effects for modulating postprandial blood glucose, and has an essential role in controlling postprandial glycemia and insulin responses due to fiber's effects on gastric emptying and macronutrient absorption in the intestine (Pereira et al., 2002; Babio et al., 2010). Decreased blood glucose levels in diabetic rats fed four types of analog rice were influenced by resistant starch levels, which can downregulate gluconeogenesis by decreasing expression of the catalytic subunit of glucose-6-phosphatase isoform 1 (C6PC1). C6PC1 is a crucial enzyme that regulates gluconeogenesis in the livers of these animals. Resistant starch was also capable of increasing the expression of glycogen synthase and glycogenin 1 , which play a role in lowering blood glucose levels through transforming glucose into glycogen in the liver (Zhou et al., 2015).

Alloxan induced hyperglycemia in experimental rats, which can stimulate formation of reactive oxygen species and reactive nitrogen species, and lead to oxidative stress. Oxidative stress can cause a significant decrease in average body weight gain, food intake, and food efficiency ratios in rats compared with NSF. Oxidative stress condition causes inflammation, decreased insulin production, and impaired insulin signaling (Elsayed et al., 2020).

Treatment with four types of analog rice that contains total phenols, dietary fiber, and resistant starch could improve weight and FER of diabetic mice. Total phenol, dietary fiber, and resistant starch in four types of analog rice can improve oxidative stress and insulin sensitivity, and increase insulin secretion from pancreatic $\beta$-cells (Hwang et al., 2005; Jeong et al., 2010; Sun et al., 2018).

Decreases in plasma LDL-c and prevention of in vivo oxidation arises from the phenol content (Gorinstein et al., 2002). Possible mechanisms include stimulation of biliary secretion of cholesterol and its excretion in feces (Prasad and Kalra, 1993), inhibition of undigested dietary cholesterol absorption or cholesterol production in the liver (Krzeminski et al., 2003). Antioxidant compounds could protect pancreatic cells from progressive damage enhanced by the absence of alloxan and other free radicals. In addition, antioxidant compounds can capture free radicals to protect against pancreatic cell damage and enhance pancreatic function.

Our study also showed that four types of analog rice can lower lipids profile, i.e., triglycerides, total cholester$\mathrm{ol}$, and LDL-c, and increase HDL-c, due to the dietary fiber content. The possible mechanisms of action include increased synthesis and excretion of bile acids and inhibition of endogenous cholesterol synthesis by short-chain 
fatty acids (SCFAs). Modifications to lipoprotein metabolism increases the number of hepatic LDL-c receptors and decreases triglyceride absorbance (Gelissen et al., 1994; Brown et al., 1999; Fukushima et al., 2000; VelázquezLópez et al., 2016). Dietary fiber can increase enzymatic activity of cholesterol-7- $\alpha$-hydroxylase, the main regulatory enzyme in hepatic conversion of cholesterol to bile acids (Roy et al., 2002), and decrease liver cholesterol. Depletion of cholesterol in the liver stimulates enzymatic activity of $\beta$-hydroxy $\beta$-methylglutaryl-coenzyme A reductase to increase endogenous cholesterol synthesis. Fermentation of dietary fiber in the gastrointestinal tract tends to modify short-chain fatty acid production, thus lowering acetate and increasing propionate synthesis. Furthermore, it reduces the synthesis of endogenous cholesterol, fatty acids, and very LDL-c (Cheng and Lai, 2000). Meta-analyses showed that resistant starch consumption can lower triglycerides, total cholesterol, LDL-c, and HDL-c (Martinez-Flores et al., 2004; Nugraheni et al., 2017; Yuan et al., 2018).

The changes to the lipid profile are supported by the ability of resistant starch to inhibit biosynthesis of fatty acids, triglycerides, and cholesterol. Inhibition is characterized by deregulated expression of sterol regulatory element-binding protein 1, a membrane-bound transcription factor that increases transcription of genes encoding biosynthetic enzymes of fatty acids, triglycerides, and cholesterol (Zhou et al., 2015). These changes may also be caused by bioactive compounds in four types of analog rice, which is in line with research stating that bioactive compounds may inhibit pancreatic lipase indigestion and modulate important lipogenic transcription factors (Ramírez-Jiménez et al., 2015).

Hyperglycemia, hyperinsulinemia, and insulin resistance can cause oxidative stress, which is involved in the pathophysiology of diabetes. Indeed, four types of analog rice consumption increased plasma antioxidant activity in diabetic mice, and plasma antioxidant activity positively impacted glucose and lipids profiles. Antioxidant activity derived from bioactive compounds, such as total phenol, can protect pancreatic cells from damage and death (Nivitabishekam et al., 2009), thus increasing insulin secretion and decreasing plasma glucose levels.

Alloxan-induced diabetic rats fed the four types of ana$\log$ rice (DAR I $\sim \mathrm{IV})$ showed increased plasma antioxidant activity than alloxan-induced diabetic rats fed a standard feed diet commercial rice (C64). High antioxidant activity protects the pancreas from damage, thus increasing insulin secretion, and tends to increase the sensitivity of insulin or reduce insulin resistance. This is in line with studies that showed administration of bioactive compounds (phenols) with antioxidant activity could protect the pancreas from damage due to oxidative stress and increase insulin sensitivity (Wu et al., 2004; Anderson,
2008; Hininger-Favier et al., 2009). Phenol compounds can increase plasma insulin levels by impacting insulin secretion by regenerating pancreatic $\beta$-cells, which is a critical factor for restoring insulin production and secretion, and reducing HOMA IR. Downregulation of peroxisome proliferator-activated receptor (PPAR) genes in the pancreas of diabetic mice shows that administering Abelmoschus esculantus (L.)-rich phenol compounds may improve glucose homeostasis and $\beta$-cell disorders through a PPAR-dependent mechanism (Erfani Majd et al., 2018). Furthermore, the phenol compounds can capture free radicals and lower oxidative stress to enhance pancreatic functioning (Gandhi et al., 2011). In addition, phenol compounds can lower HOMA IR in diabetic mice, thus increasing insulin sensitivity through upregulating expression of glucose transporters and receptors and promoting glucose in the peripheral tissues of diabetic rats. Phenol also selectively inhibits glycogen synthase kinase$3 \beta$ activity and central insulin resistance, oxidative stress, and pro-inflammatory cytokines, thus improving pancreatic function (Jung et al., 2011; Gomaa et al., 2019).

This study shows that the dietary fiber content of four types of analog rice positively impacts insulin sensitivity. This is in line with the studies reporting that consuming foods containing high levels of dietary fiber, such as cereals, tend to improve insulin sensitivity by lowering insulin resistance (Weickert et al., 2006). Dietary fiber can improve $\beta$-cell function, increase insulin levels, lower insulin resistance, and restore pancreatic $\beta$-cell function (Erukainure et al., 2013). Soluble dietary fiber is viscous in shape, and can bind bile acids and cholesterol to lower insulin resistance and inflammation. Moreover, dietary fiber is fermented in the intestines, and increases production of SCFAs that can regulate the sympathetic and parasympathetic nervous system, which controls glucose and cholesterol metabolism and insulin resistance (Kimura et al., 2011; Dong et al., 2019).

Alloxan induced diabetes in rats and increased AI. Alloxan impacts metabolic process mediated by insulin that converts sugar and fat into energy. Thus, impaired insulin secretion and function affects blood glucose, cholesterol, and triglyceride levels and, in diabetes, decreases HDL-c levels. Therefore, diabetes has potential to increase AI. Low HDL-c and high cholesterol levels increase plaque formation in arterial walls, gradually clogging the arteries, and leading to heart attacks and strokes. Therefore, the rise of $\mathrm{AI}$ in experimental rats should be monitored and immediately reduced. High total cholesterol and low HDL-c levels tend to represent elevated AI. This condition is a main risk factors for coronary heart disease. Indeed, diabetes increases hyperlipidemia and atherosclerosis since the liver and some other tissues convert the oxidation and metabolism of fatty acids, cholesterol synthesis, and phospholipids. We demonstrated a decrease 
in AI after the four types of analog rice consumption, which tends to be related to the effects of bioactive compounds (phenols), dietary fiber, starch resistance, and the absence of plasma antioxidant activity. Some studies have shown that resistant starch can increase HDL-c levels and lower total cholesterol profiles (Kim et al., 2003).

The four types of analog rice used in this study contained resistant starch that can lower insulin resistance, pancreatic $\beta$-cell mass, increase glucagon-like peptide- 1 (GLP-1) production to mediate glucose-dependent insulin secretion and increase insulin levels (Farilla et al., 2002; Shen et al., 2011). Consumption of resistant starch also decreases insulin resistance (Harazaki et al., 2014), which plays a role as a prebiotic inside colon. Resistant starch is fermented by probiotic bacteria, such as Lactobacillus sp., thus producing SCFA, which increases production and secretion of GLP-1 in intestinal walls. GLP-1 induces proliferation of pancreatic $\beta$-cells, increase insulin secretion, and controls glucagon. Propionic and valeric acids are two types of SCFA, which can improve insulin sensitivity through, at least in part, GPR41 by stimulating absorption of insulin-induced glucose into adipocytes and basal glucose into skeletal muscle cells. Therefore, there is a possibility that GPR41 becomes a new molecular target to control high blood glucose levels associated with disease conditions, such as type 2 diabetes (Han et al., 2014). Resistant starch can improve insulin resistance via increasing $\mathrm{mRNA}$ and protein levels of $\mathrm{CD} 11 \mathrm{c}$ in adipose tissue (Harazaki et al., 2014). The resistant starch in four types of analog rice was capable of increasing insulin sensitivity (lowering insulin resistance). Fermentation of RS in the intestine produces SCFA, acetate and propionate, which may impact insulin sensitivity or decrease insulin resistance (Wang et al., 2019). This is in line with previous studies, which show that RS consumption can lower insulin sensitivity and increase plasma insulin levels (Bindels et al., 2017).

Overall, this study showed that four types of analog rice containing bioactive compounds, dietary fiber and resistant starch positively impacts serum insulin levels and decreases HOMA IR, indicative of increased insulin sensitivity and HOMA $\beta$. Improvements in three indicators related to pancreatic function were positively impacted by fasting blood sugar regulation in rats with diabetes. Analog rice I, II, III, and IV consumption improved fasting glucose levels, body weight gain, FERs, and triglyceride, total cholesterol, and LDL-c levels in the blood of diabetic rats. Improvements to the antioxidant activity of plasma, serum insulin, HOMA IR, HOMA $\beta$, and AI were monitored during this study. The four types of analog rice containing phenol, dietary fiber, and resistant starch compounds positively benefited serum marker repair in diabetic rats.

\section{AUTHOR DISCLOSURE STATEMENT}

The authors declare no conflict of interest.

\section{AUTHOR'S CONTRIBUTION}

M. Nugraheni: Designing and conducting research, as well as analyzing and interpreting data, contributing to reagents, materials, and wrote papers. S. Puwanti: conduct research, analyze data, contributed to reagents, materials, and wrote papers. P. Ekawatiningsih: carried out research, contributed to materials, analyzed data, interpreted data, and wrote papers.

\section{REFERENCES}

Ademiluyi AO, Oboh G. Soybean phenolic-rich extracts inhibit key-enzymes linked to type 2 diabetes ( $\alpha$-amylase and $\alpha$-glucosidase) and hypertension (angiotensin I converting enzyme) in vitro. Exp Toxicol Pathol. 2013. 65:305-309.

Agunbiade OS, Ojezele OM, Ojezele JO, Ajayi AY. Hypoglycaemic activity of Commelina africana and Ageratum conyzoides in relation to their mineral composition. Afr Health Sci. 2012. 12: 198-203.

Agustiniano-Osornio JC, González-Soto RA, Flores-Huicochea E, Manrique-Quevedo N, Sánchez-Hernández L, Bello-Pérez LA. Resistant starch production from mango starch using a singlescrew extruder. J Sci Food Agric. 2005. 85:2105-2110.

Anderson RA. Chromium and polyphenols from cinnamon improve insulin sensitivity. Proc Nutr Soc. 2008. 67:48-53.

Aslani Z, Alipour B, Bahadoran Z, Bagherzadeh F, Mirmiran P. Effect of lentil sprouts on glycemic control in overweight and obese patients with type 2 diabetes. Int J Nutr Food Sci. 2015a. 4:10-14.

Aslani Z, Mirmiran P, Alipur B, Bahadoran Z, Abbassalizade Farhangi M. Lentil sprouts effect on serum lipids of overweight and obese patients with type 2 diabetes. Health Promot Perspect. 2015b. 5:215-224.

Asrullah M, Lestari LA, Helmyati S, Farmawati A. The effect of mung bean sprouts (Phaseolus radiatus L.) to lipid profile of male Sprague-Dawley rats fed with high-fat diet. AIP Conf Proc. 2016. 1755:140001. https://doi.org/10.1063/1.4958562

Audu SS, Aremu MO. Effect of processing on chemical composition of red kidney bean (Phaseolus vulgaris L.) flour. PakJ Nutr. 2011. 10:1069-1075.

Babio N, Balanza R, Basulto J, Bulló M, Salas-Salvadó J. Dietary fibre: influence on body weight, glycemic control and plasma cholesterol profile. Nutr Hosp. 2010. 25:327-340.

Beloshapka AN, Buff PR, Fahey GC, Swanson KS. Compositional analysis of whole grains, processed grains, grain co-products, and other carbohydrate sources with applicability to pet animal nutrition. Foods. 2016. 5:23. https://doi.org/10.3390/ foods5020023

Benzie IFF, Strain JJ. The ferric reducing ability of plasma (FRAP) as a measure of "antioxidant power": the FRAP assay. Anal Biochem. 1996. 239:70-76.

Bindels LB, Segura Munoz RR, Gomes-Neto JC, Mutemberezi V, Martínez I, Salazar N, et al. Resistant starch can improve insulin sensitivity independently of the gut microbiota. Microbiome. 2017. 5:12. https://doi.org/10.1186/s40168-017-0230-5 
Brown L, Rosner B, Willett WW, Sacks FM. Cholesterol-lowering effects of dietary fiber: a meta-analysis. Am J Clin Nutr. 1999. 69:30-42.

Chalorcharoenying W, Lomthaisong K, Suriharn B, Lertrat K. Germination process increases phytochemicals in corn. Int Food Res J. 2017. 24:552-558.

Cheng HH, Lai MH. Fermentation of resistant rice starch produces propionate reducing serum and hepatic cholesterol in rats. J Nutr. 2000. 130:1991-1995.

Ciabotti S, Silva ACBB, Juhasz ACP, Mendonça CD, Tavano OL, Mandarino JMG, et al. Chemical composition, protein profile, and isoflavones content in soybean genotypes with different seed coat colors. Int Food Res J. 2016. 23:621-629.

Dahiya PK, Linnemann AR, Van Boekel MA, Khetarpaul N, Grewal RB, Nout MJ. Mung bean: technological and nutritional potential. Crit Rev Food Sci Nutr. 2015. 55:670-688.

Devi CB, Kushwaha A, Kumar A. Sprouting characteristics and associated changes in nutritional composition of cowpea (Vigna unguiculata). J Food Sci Technol. 2015. 52:6821-6827.

Dong Y, Chen L, Gutin B, Zhu H. Total, insoluble, and soluble dietary fiber intake and insulin resistance and blood pressure in adolescents. Eur J Clin Nutr. 2019. 73:1172-1178.

Dundar AN, Gocmen D. Effects of autoclaving temperature and storing time on resistant starch formation and its functional and physicochemical properties. Carbohydr Polym. 2013. 97: 764-771.

Elkhalifa AEO, Bernhardt R. Influence of grain germination on functional properties of sorghum flour. Food Chem. 2010. 121:387-392.

Elsayed RH, Kamel EM, Mahmoud AM, El-Bassuony AA, BinJumah M, Lamsabhi AM, et al. Rumex dentatus L. phenolics ameliorate hyperglycemia by modulating hepatic key enzymes of carbohydrate metabolism, oxidative stress and PPAR $\gamma$ in diabetic rats. Food Chem Toxicol. 2020. 138:111202. https:// doi.org/10.1016/j.fct.2020.111202

Erfani Majd N, Tabandeh MR, Shahriari A, Soleimani Z. Okra (Abelmoscus esculentus) improved islets structure, and downregulated PPARs gene expression in pancreas of high-fat diet and streptozotocin-induced diabetic rats. Cell J. 2018. 20:3140.

Erukainure OL, Ebuehi OAT, Adeboyejo FO, Okafor EN, Muhammad A, Elemo GN. Fiber-enriched biscuit enhances insulin secretion, modulates $\beta$-cell function, improves insulin sensitivity, and attenuates hyperlipidemia in diabetic rats. PharmaNutrition. 2013. 1:58-64.

Farilla L, Hui H, Bertolotto C, Kang E, Bulotta A, Di Mario U, et al. Glucagon-like peptide-1 promotes islet cell growth and inhibits apoptosis in Zucker diabetic rats. Endocrinology. 2002. 143: 4397-4408.

Foschia M, Peressini D, Sensidoni A, Brennan CS. The effects of dietary fibre addition on the quality of common cereal products. J Cereal Sci. 2013. 58:216-227.

Fukushima M, Nakano M, Morii Y, Ohashi T, Fujiwara Y, Sonoyama K. Hepatic LDL receptor mRNA in rats is increased by dietary mushroom (Agaricus bisporus) fiber and sugar beet fiber. J Nutr. 2000. 130:2151-2156.

Gan RY, Lui WY, Wu K, Chan CL, Dai SH, Sui ZQ, et al. Bioactive compounds and bioactivities of germinated edible seeds and sprouts: an updated review. Trends Food Sci Technol. 2017. 59:1-14.

Gandhi GR, Ignacimuthu S, Paulraj MG. Solanum torvum Swartz. fruit containing phenolic compounds shows antidiabetic and antioxidant effects in streptozotocin induced diabetic rats. Food Chem Toxicol. 2011. 49:2725-2733.

Gelissen IC, Brodie B, Eastwood MA. Effect of Plantago ovata (psyllium) husk and seeds on sterol metabolism: studies in normal and ileostomy subjects. Am J Clin Nutr. 1994. 59:395-400.
Gomaa AA, Makboul RM, Al-Mokhtar MA, Nicola MA. Polyphenol-rich Boswellia serrata gum prevents cognitive impairment and insulin resistance of diabetic rats through inhibition of GSK3 $\beta$ activity, oxidative stress and pro-inflammatory cytokines. Biomed Pharmacother. 2019. 109:281-292.

Gorinstein S, Leontowicz H, Lojek A, Leontowicz M, Ciz M, Krzeminski R, et al. Olive oils improve lipid metabolism and increase antioxidant potential in rats fed diets containing cholesterol. J Agric Food Chem. 2002. 50:6102-6108.

Han JH, Kim IS, Jung SH, Lee SG, Son HY, Myung CS. The effects of propionate and valerate on insulin responsiveness for glucose uptake in 3T3-L1 adipocytes and C2C12 myotubes via G protein-coupled receptor 41. PLoS One. 2014. 9:e95268. https://doi.org/10.1371/journal.pone.0095268

Harazaki T, Inoue S, Imai C, Mochizuki K, Goda T. Resistant starch improves insulin resistance and reduces adipose tissue weight and $\mathrm{CD} 11 \mathrm{c}$ expression in rat OLETF adipose tissue. Nutrition. 2014. 30:590-595.

Hininger-Favier I, Benaraba R, Coves S, Anderson RA, Roussel AM. Green tea extract decreases oxidative stress and improves insulin sensitivity in an animal model of insulin resistance, the fructose-fed rat. J Am Coll Nutr. 2009. 28:355-361.

Hwang HJ, Kim SW, Lim JM, Joo JH, Kim HO, Kim HM, et al. Hypoglycemic effect of crude exopolysaccharides produced by a medicinal mushroom Phellinus baumii in streptozotocin-induced diabetic rats. Life Sci. 2005. 76:3069-3080.

Jeong SC, Jeong YT, Yang BK, Islam R, Koyyalamudi SR, Pang G, et al. White button mushroom (Agaricus bisporus) lowers blood glucose and cholesterol levels in diabetic and hypercholesterolemic rats. Nutr Res. 2010. 30:49-56.

Jung JY, Lim Y, Moon MS, Kim JY, Kwon O. Onion peel extracts ameliorate hyperglycemia and insulin resistance in high fat diet/streptozotocin-induced diabetic rats. Nutr Metab. 2011. 8:18. https://doi.org/10.1186/1743-7075-8-18

Jyoshna E, Hymavathi TV. Review of studies on effect of resistant starch supplementation on glucose and insulin. J Pharmacog Phytochem. 2017. 6:55-58.

Kementerian Kesehatan Republik Indonesia. Laporan Nasional Riskesdas 2018. Riskesdas T, editor. Kementerian Kesehatan Republik Indonesia, Jakarta, Indonesia. 2018. p 154-166.

Khang DT, Dung TN, Elzaawely AA, Xuan TD. Phenolic profiles and antioxidant activity of germinated legumes. Foods. 2016. 5:27. https://doi.org/10.3390/foods5020027

Kim WK, Chung MK, Kang NE, Kim MH, Park OJ. Effect of resistant starch from corn or rice on glucose control, colonic events, and blood lipid concentrations in streptozotocin-induced diabetic rats. J Nutr Biochem. 2003. 14:166-172.

Kimura I, Inoue D, Maeda T, Hara T, Ichimura A, Miyauchi S, et al. Short-chain fatty acids and ketones directly regulate sympathetic nervous system via $G$ protein-coupled receptor 41 (GPR41). Proc Natl Acad Sci. 2011. 108:8030-8035.

Krzeminski R, Gorinstein S, Leontowicz H, Leontowicz M, Gralak $\mathrm{M}$, Czerwinski J, et al. Effect of different olive oils on bile excretion in rats fed cholesterol-containing and cholesterol-free diets. J Agric Food Chem. 2003. 51:5774-5779.

Lee SC, Prosky L, De Vries JW. Determination of total, soluble, and insoluble dietary fiber in foods-enzymatic-gravimetric method, MES-TRIS buffer: collaborative study. J AOAC Int. 1992. 75:395-416.

Lemmens E, Moroni AV, Pagand J, Heirbaut P, Ritala A, Karlen $Y$, et al. Impact of cereal seed sprouting on its nutritional and technological properties: a critical review. Compr Rev Food Sci Food Saf. 2019. 18:305-328.

Liyanage R, Kiramage C, Visvanathan R, Jayathilake C, Weththasinghe $\mathrm{P}$, Bangamuwage R, et al. Hypolipidemic and hypoglycemic potential of raw, boiled, and sprouted mung beans (Vigna radiata L. Wilczek) in rats. J Food Biochem. 2018. 
42:e12457. https://doi.org/10.1111/jfbc. 12457

López-Martínez LX, Leyva-López N, Gutiérrez-Grijalva EP, Heredia JB. Effect of cooking and germination on bioactive compounds in pulses and their health benefits. J Funct Foods. 2017. 38:624-634.

Mahmoud AM, Ashour MB, Abdel-Moneim A, Ahmed OM. Hesperidin and naringin attenuate hyperglycemia-mediated oxidative stress and proinflammatory cytokine production in high fat fed/streptozotocin-induced type 2 diabetic rats. J Diabetes Complications. 2012. 26:483-490.

Mandalari G, Tomaino A, Arcoraci T, Martorana M, Lo Turco V, Cacciola F, et al. Characterization of polyphenols, lipids and dietary fibre from almond skins (Amygdalus communis L.). J Food Compos Anal. 2010. 23:166-174.

Martinez-Flores HE, Chang YK, Martinez-Bustos F, Sgarbieri V. Effect of high fiber products on blood lipids and lipoproteins in hamsters. Nutr Res. 2004. 24:85-93.

Megat Rusydi MR, Azrina A. Effect of germination on total phenolic, tannin and phytic acid contents in soy bean and peanut. Int Food Res J. 2012. 19:673-677.

Megat Rusydi MR, Noraliza CW, Azrina, A, Zulkhairi A. Nutritional changes in germinated legumes and rice varieties. Int Food Res J. 2011. 18:705-713.

Muruganandan S, Srinivasan K, Gupta S, Gupta PK, Lal J. Effect of mangiferin on hyperglycemia and atherogenicity in streptozotocin diabetic rats. J Ethnopharmacol. 2005. 97:497-501.

Nivitabishekam SN, Asad M, Prasad VS. Pharmacodynamic interaction of Momordica charantia with rosiglitazone in rats. Chem Biol Interact. 2009. 177:247-253.

Nugraheni M, Hamidah S, Auliana R. A Potential of Coleus tuberosus crackers rich in resistant starch type 3 improves glucose and lipid profile of alloxan-induced diabetic mice. Curr Res Nutr Food Sci. 2017. 5:308-319.

Obiro WC, Zhang T, Jiang B. The nutraceutical role of the Phaseolus vulgaris alpha-amylase inhibitor. Br J Nutr. 2008. 100:1-12.

Pantidos N, Boath A, Lund V, Conner S, McDougall GJ. Phenolicrich extracts from the edible seaweed, Ascophyllum nodosum, inhibit $\alpha$-amylase and $\alpha$-glucosidase: potential anti-hyperglycemic effects. J Funct Foods. 2014. 10:201-209.

Pereira MA, Jacobs DR Jr, Pins JJ, Raatz SK, Gross MD, Slavin JL, et al. Effect of whole grains on insulin sensitivity in overweight hyperinsulinemic adults. Am J Clin Nutr. 2002. 75:848-855.

Prasad K, Kalra J. Oxygen free radicals and hypercholesterolemic atherosclerosis: effect of vitamin E. Am Heart J. 1993. 125:958973.

Raigond P, Ezekiel R, Singh B, Dutt S, Joshi A, Rinki. Resistant starch production technologies - a review. Potato J. 2015. 42: 81-94.

Ramírez-Jiménez AK, Reynoso-Camacho R, Tejero ME, LeónGalván F, Loarca-Piña G. Potential role of bioactive compounds of Phaseolus vulgaris L. on lipid-lowering mechanisms. Food Res Int. 2015. 76:92-104.

Reddy CK, Haripriya S, Noor Mohamed A, Suriya M. Preparation and characterization of resistant starch III from elephant foot yam (Amorphophallus paeonifolius) starch. Food Chem. 2014. $155: 38-44$

Reeves PG, Nielsen FH, Fahey GC Jr. AIN-93 purified diets for laboratory rodents: final report of the American Institute of Nutrition ad hoc writing committee on the reformulation of the AIN-76A rodent diet. J Nutr. 1993. 123:1939-1951.

Roy S, Freake HC, Fernandez ML. Gender and hormonal status affect the regulation of hepatic cholesterol $7 \alpha$-hydroxylase activity and mRNA abundance by dietary soluble fiber in the guinea pig. Atherosclerosis. 2002. 163:29-37.

Sai-Ut S, Ketnawa S, Chaiwut P, Rawdkuen S. Biochemical and functional properties of proteins from red kidney, navy and adzuki beans. As J Food Ag-Ind. 2009. 2:493-504.
Sharma S, Saxena DC, Riar CS. Analysing the effect of germination on phenolics, dietary fibres, minerals and $\gamma$-amino butyric acid contents of barnyard millet (Echinochloa frumentaceae). Food Biosci. 2016. 13:60-68.

Shen L, Keenan MJ, Raggio A, Williams C, Martin RJ. Dietary-resistant starch improves maternal glycemic control in GotoKakizaki rat. Mol Nutr Food Res. 2011. 55:1499-1508.

Singleton VL, Orthofer R, Lamuela-Raventós RM. Analysis of total phenols and other oxidation substrates and antioxidants by means of Folin-Ciocalteu reagent. Methods Enzymol. 1999. 29:152-178

Sreerama YN, Takahashi Y, Yamaki K. Phenolic antioxidants in some Vigna species of legumes and their distinct inhibitory effects on $\alpha$-glucosidase and pancreatic lipase activities. J Food Sci. 2012. 77:C927-C933.

Subagio H, Aqil M. Perakitan dan pengembangan varietas unggul sorgum untuk pangan, pakan, dan bioenergi. Iptek Tanaman Pangan. 2014. 9:39-50.

Sun H, Ma X, Zhang S, Zhao D, Liu X. Resistant starch produces antidiabetic effects by enhancing glucose metabolism and ameliorating pancreatic dysfunction in type 2 diabetic rats. Int J Biol Macromol. 2018. 110:276-284.

Tiwari BK, Pandey KB, Abidi AB, Rizvi SI. Markers of oxidative stress during diabetes mellitus. J Biomark. 2013. 2013:378790. https://doi.org/10.1155/2013/378790

Velázquez-López L, Muñoz-Torres AV, García-Peña C, LópezAlarcón M, Islas-Andrade S, Escobedo-de la Peña J. Fiber in diet is associated with improvement of glycated hemoglobin and lipid profile in mexican patients with type 2 diabetes. J Diabetes Res. 2016. 2016:2980406. https://doi.org/10.1155/ 2016/2980406

Wallace TM, Levy JC, Matthews DR. Use and abuse of HOMA modeling. Diabetes Care. 2004. 27:1487-1495.

Wang Y, Chen J, Song YH, Zhao R, Xia L, Chen Y, et al. Effects of the resistant starch on glucose, insulin, insulin resistance, and lipid parameters in overweight or obese adults: a systematic review and meta-analysis. Nutr Diabetes. 2019. 9:19. https:// doi.org/10.1038/s41387-019-0086-9

Weickert MO, Möhlig M, Schöfl C, Arafat AM, Otto B, Viehoff H, et al. Cereal fiber improves whole-body insulin sensitivity in overweight and obese women. Diabetes Care. 2006. 29:775780.

Wu LY, Juan CC, Ho LT, Hsu YP, Hwang LS. Effect of green tea supplementation on insulin sensitivity in Sprague-Dawley rats. J Agric Food Chem. 2004. 52:643-648.

Xue Z, Wang C, Zhai L, Yu W, Chang H, Kou X, et al. Bioactive compounds and antioxidant activity of mung bean (Vigna radiata L.), soybean (Glycine max L.) and black bean (Phaseolus vulgaris L.) during the germination process. Czech J Food Sci. 2016. 34: 68-78.

Yuan HC, Meng Y, Bai H, Shen DQ, Wan BC, Chen LY. Meta-analysis indicates that resistant starch lowers serum total cholesterol and low-density cholesterol. Nutr Res. 2018. 54:1-11.

Zhang G, Xu Z, Gao Y, Huang X, Zou Y, Yang T. Effects of germination on the nutritional properties, phenolic profiles, and antioxidant activities of buckwheat. J Food Sci. 2015. 80:H1111H1119.

Zhang H, Jin Z. Preparation of resistant starch by hydrolysis of maize starch with pullulanase. Carbohydr Polym. 2011. 83: 865-867.

Zhou Z, Wang F, Ren X, Wang Y, Blanchard C. Resistant starch manipulated hyperglycemia/hyperlipidemia and related genes expression in diabetic rats. Int J Biol Macromol. 2015. 75:316321.

Zou Y, Lu Y, Wei D. Hypocholesterolemic effects of a flavonoidrich extract of Hypericum perforatum L. in rats fed a cholesterolrich diet. J Agric Food Chem. 2005. 53:2462-2466. 